\title{
SOSIALISASI PENTINGNYA POTENSI WISATA BUDAYA DI DESA GEGEMPALAN KECAMATAN CIKONENG KABUPATEN CIAMIS
}

\section{SOCIALIZATION OF THE IMPORTANCE OF CULTURAL TOURISM POTENTIALS IN GEGEMPALAN VILLAGE, CIKONENG DISTRICT, CIAMIS REGENCY}

\author{
Sri Pajriah*, Aan Suryana, Dewi Ratih \\ Prodi Pendidikan Sejarah, FKIP, Universitas Galuh \\ *Email: sripajriah@yahoo.co.id \\ (Diterima 14-01-2021; Disetujui 08-03-2021)
}

\begin{abstract}
ABSTRAK
Kegiatan pengabdian dosen kepada masyarakat yang dilakukan mengambil judul "Sosialisasi Tentang Pentingnya Potensi Wisata Budaya di Desa Gegempalan Kecamatan Cikoneng Kabupaten Ciamis". Sasaran yang dituju dalam pengabdian ini adalah masyarakat yang memiliki pemahaman kurang terhadap manfaat dan pentingnya pengelolaan wisata sejarah dan budaya yang ada di Desa Gegempalan Kecamatan Cikoneng Kabupaten Ciamis. Hal ini dilakukan supaya masyarakat mampu meningkatkan pendapatan dan kesejahteraan mereka. Metode yang digunakan dalam kegiatan pengabdian ini adalah dengan metode sosialisasi yang disampaikan secara lisan. Adapun hasil kegiatan pengabdian secara khususnya dapat meningkatkan pendapatan dan kesejahteraan keluarga atau masyarakat melalui pengelolaan potensi wisata sejarah dan budaya yang ada di daerahnya. Kesimpulan dari pengabdian ini adalah kegiatan sosialisasi pentingnya potensi wisata budaya bagi masyarakat yang ada di Desa Gegempalan berjalan dengan lancar sesuai dengan apa yang direncanakan, meskipun belum semua memahami tentang pentingnya pengelolaan wisata budaya yang ada di desa Gegempalan. Kegiatan sosialisasi ini mendapatkan respon yang sangat baik, hal ini dibuktikan dengan keaktifan peserta sosialisasi yang diikuti tokoh masyarakat sampai tuntas. Berdasarkan evaluasi yang telah dilakukan dapat diajukan beberapa saran yaitu, waktu pelaksanaan pengabdian perlu ditambah, supaya tujuan kegiatan dapat dicapai sesuai dengan harapan, namun dengan konsekuensi penambahan biaya. Adanya kegiatan lanjutan yang berupa sosialisasi sejenis dimana hal ini dilakukan secara kontinue, sehingga mampu meningkatkan pemahaman masyarakat tentang pengelolaan potensi wisata budaya.
\end{abstract}

Kata Kunci: Sosialisasi, Potensi Wisata Budaya, Gegempalan

\section{ABSTRACT}

The title of lecturers' community service activities carried out is "Socialization of the Importance of Cultural Tourism Potentials in Gegempalan Village, Cikoneng District, Ciamis Regency". Its target is people with a lack of understanding of the benefit and importance of managing historical and cultural tourism in Gegempalan Village, Cikoneng District, Ciamis Regency. This is conducted to enable people to increase their income and welfare. The method used in this service activity is the socialization method which is conveyed orally. The result of community service activities, in particular, can increase the income and welfare of the family or community through managing the potential of historical and cultural tourism in the area. The conclusion of this service showed that the socialization of the importance of the potential for cultural tourism for the people in Gegempalan Village run well according to what was planned, although not all of them understand the importance of managing cultural tourism in Gegempalan village. This socialization activity received a very good response. This was evidenced by the active participation of the socialization participants and community leaders also attended it all the way through. Based on the evaluation carried out, several suggestions can be made, namely, the time for the implementation of the service needs to be increased to achieved the objectives of the activity as expected, but with the consequence of increasing costs. The existence of follow-up similar socialization activities are supposed to be carried out continuously to increase public understanding of the management of the potential for cultural tourism.

Keywords: Socialization, Potential of Cultural Tourism, Gegempalan 
Sosialisasi Pentingnya Potensi Wisata Budaya di Desa Gegempalan Kecamatan Cikoneng Kabupaten Ciamis Sri Pajriah, Aan Suryana, Dewi Ratih

\section{PENDAHULUAN}

Wisata budaya memiliki peranan penting dalam meningkatkan kesejahteraan masyarakat sekitar. Salah satunya, wisata budaya yang ada di Desa Gegempalan. Seperti makam Bupati Galuh yaitu, Kusumadinata I dan Kusumadinata II, Batu Panghiasan, Batu Tapak Kidang, serta upacara Sedekah Pasarean yang dilaksanakan setiap tahun di bulan Oktober (Hasil Wawancara dengan Kepala Desa Tanggal 6 Maret 2019).

Desa Gegempalan terletak di bagian barat Kabupaten Ciamis, dan merupakan salah satu desa di Kecamatan Cikoneng Kabupaten Ciamis. Batas-batas wilayah Desa Gegempalan adalah sebelah utara berbatasan dengan Desa Imbanagara Raya, Kabupaten Ciamis dan Desa Cimari, Kecamatan Cikoneng. Sebelah Selatan berbatasan dengan Sungai Citanduy/Kabupaten Tasikmalaya. Sebelah Barat berbatasan dengan Desa Cikoneng, Kecamatan Cikoneng. Sebelah Timur berbatasan dengan Desa Panyingkiran, Kecamatan Ciamis. Wilayah Desa Gegempalan secara garis besar terdiri atas dataran tinggi dengan bentuk daratan dan perbukitan. Daerah utara dengan bentuk daratan berbukit dan daerah selatan berbentuk dataran (https://gegempalan.web.id/gambaran-umum).

Pada saat ini wisata sejarah dan budaya adalah salah satu sektor pendapatan yang bisa diandalkan oleh masyarakat guna meningkatkan kesejahteraan ekonomi. Namun, kenyataannya masih banyak masyarakat yang belum memahami potensi tersebut, sehingga banyaknya dampak dan keuntungan dari potensi tersebut menjadi kurang efektif dan efisien. Dalam hal ini, pemerintah harus berperan dalam memberdayakan masyarakat Desa Gegempalan, karena akan percuma ketika tempat wisata sejarah dan budaya yang ada dan berusaha dikembangkan, namun masyarakat ternyata tidak mampu melihat peluang dan manfaat yang berdampak baik bagi masyarakat sendiri. Hal ini sesuai dengan isi UndangUndang Nomor 10 Tahun 2009 tentang kepariwisataan yang menyatakan bahwa pembangunan kepariwisataan diperlukan untuk mendorong pemerataan kesempatan berusaha dan memperoleh manfaat serta mampu menghadapi tantangan perubahan kehidupan lokal, nasional, dan global. Sama halnya dengan beberapa situs sejarah dan budaya yang ada di Desa Gegempalan bisa dikelola oleh masyarakat dan desa dengan baik, sehingga mampu meningkatkan kesejahteraan ekonomi.

Berdasarkan kondisi di atas, maka dilakukan kegiatan pengabdian mengenai potensi wisata sejarah dan budaya di Desa Gegempalan Kecamatan Cikoneng Kabupaten Ciamis, sehingga diharapkan dengan adanya kegiatan pengabdian ini masyarakat akan lebih memahami tentang urgennya pengelolaan potensi wisata sejarah dan budaya yang ada di sekitar lingkungan mereka dan selanjutnya akan mampu meningkatkan kesejahteraan 
mereka. Kegiatan pengabdian merupakan salah satu tugas pokok dosen yang tercantum dalam Tridharma perguruan tinggi.

Berdasarkan penjelasan di atas, maka akan dilakukan kegiatan pengabdian dengan judul "Sosialisasi Pentingnya Potensi Wisata Sejarah dan Budaya Di Desa Gegempalan Kecamatan Cikoneng Kabupaten Ciamis".

\section{BAHAN DAN METODE}

Metode yang digunakan dalam kegiatan sosilaisasi ini adalah ceramah. Untuk mencapai tujuan yang telah ditetapkan, maka dilakukan langkah-langkah sebagai berikut:

1. Menghubungi masyarakat Desa Gegempalan untuk mendiskusikan tema yang akan dijadikan pengabdian.

2. Menyelenggarakan kegiatan sosialisasi dengan materi: Sosialisasi Pentingnya Potensi Wisata Budaya di Desa Gegempalan Kecamatan Cikoneng Kabupaten Ciamis.

\section{HASIL DAN PEMBAHASAN}

\section{A. Keadaan Umum Lokasi Pengabdian}

1. Letak dan Luas

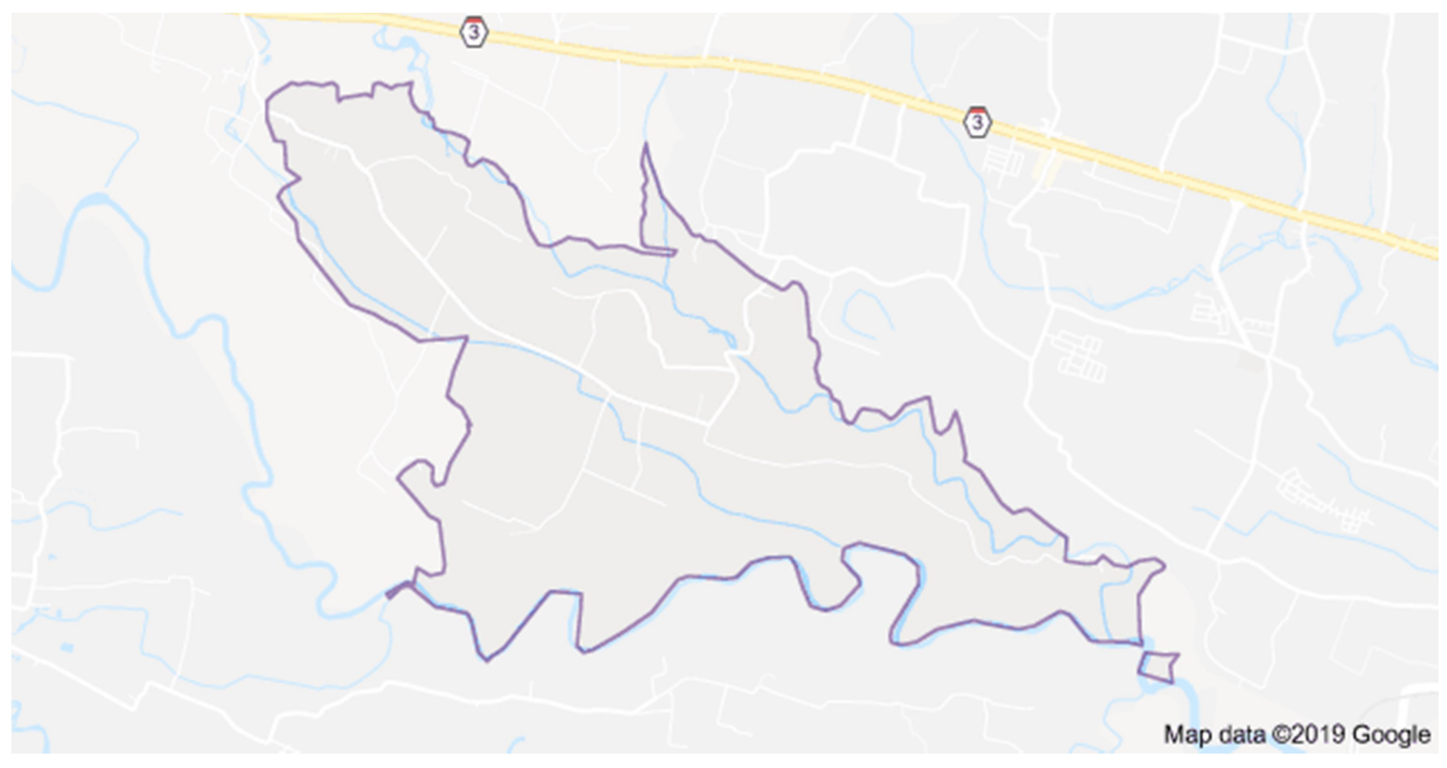

Gambar 1. Denah Desa Gegempalan Kecamatan Cikoneng Kabupaten Ciamis

\section{a. Batas Desa}

Desa Gegempalan terletak di bagian barat Kabupaten Ciamis dan merupakan salah satu desa di Kecamatan Cikoneng. Adapun Kabupaten Ciamis berada pada koordinat $108^{\circ}$ 
40' Bujur Timur dan 740'20" sampai dengan 741'20" Lintang Selatan. Batas-batas wilayah Desa Gegempalan sebagai berikut:

1. Sebelah Utara: Desa Imbanagara Raya, Kabupaten Ciamis dan Desa Cimari, Kecamatan Cikoneng.

2. Sebelah Selatan: Sungai Citanduy/Kabupaten Tasikmalaya

3. Sebelah Barat : Desa Cikoneng, Kecamatan Cikoneng

4. Sebelah Timur : Desa Panyingkiran, Kecamatan Ciamis

Wilayah Desa Gegempalan secara garis besar terdiri atas dataran tinggi dengan bentuk daratan dan perbukitan. Daerah utara denganut bentuk daratan berbukit dan daerah selatan berbentuk dataran. Ketinggian pada bagian daerah dataran pada 450 meter dpl dan pada perbukitan dengan ketinggian lebih kurang 100 meter dpl. Desa Gegempalan terdiri atas 5 dusun yaitu Dusun Desa, Gareumpay, Majaganda, Bojongsari, dan Cikanyere. Letak kantor desa di Dusun Desa. Sekarang Desa Gegempalan dipimpin oleh kepala desa Wawan Munawar yang bertempat tinggal di Dusun Cikanyere, beliau mulai menjabat sejak tahun 2016 sampai sekarang (https://gegempalan.web.id/gambaran-umum).

\section{b. Luas Wilayah}

1. Luas Desa : 331.695 ha

2. Status Tanah
1). Tanah Darat
: 156.605 ha
2). Tanah Pekarangan
: 50 ha
3). Sarana Umum
: 8.055 ha
4). Perkantoran
: 0.10 ha
5). Sungai
: 3.5 ha
6). Sawah
: 83.895 ha
7). Kolam
: 27 ha
8). Kuburan
: 2.54 ha

3. Jumlah Penduduk

a. Jumlah KK : 1.389 orang

1). Jumlah Penduduk Laki-laki : 2.501 orang

2). Jumlah Penduduk Wanita : 2.400 orang

b. Jumlah Penduduk Perdusun

1). Dusun Desa 

a. Jumlah KK
: 294 orang
b. Penduduk Laki-laki : 511 orang
c. Penduduk Wanita : 499 orang

2). Dusun Majaganda
a. Jumlah KK : 307 orang
b. Penduduk Laki-laki : 530 orang
c. Penduduk Wanita :513 orang

3). Dusun Gareumpay
a. Jumlah KK
: 369 orang
b. Penduduk Laki-laki
: 628 orang
c. Penduduk Wanita
: 614 orang

4). Dusun Bojongsari
a. Jumlah KK : 235 orang
b. Penduduk Laki-laki : 445 orang
c. Penduduk Wanita :410 orang

5). Dusun Cikanyere
a. Jumlah KK : 184 orang
b. Penduduk Laki-laki : 387 orang
c. Penduduk Wanita : 364 orang

c. Penduduk Kelompok Umur Perdesa

$$
\begin{aligned}
& \text { Usia } 0 \text { - } 4 \text { tahun : } 420 \text { orang } \\
& \begin{aligned}
\text { L } & : 232 \text { orang } \\
P \quad: & 188 \text { orang }
\end{aligned}
\end{aligned}
$$

Usia 5 - 9 tahun : 420 orang

L : 209 orang

P : 211 orang

Usia 10 - 14 tahun : 406 orang

L : 199 orang

P : 207 orang

Usia 15 - 19 tahun : 417 orang

L : 210 orang

P : 207 orang

Usia $20-24$ tahun : 398 orang

L : 197 orang 
P : 201 orang

Usia 25 - 29 tahun : 378 orang

L : 182 orang

P : 196 orang

Usia $30-34$ tahun : 352 orang

L : 180 orang

P : 172 orang

Usia 35 - 39 tahun : 354 orang

L : 189 orang

P : 165 orang

Usia $40-44$ tahun : 327 orang

L : 169 orang

P : 158 orang

Usia 45 - 49 tahun : 283 orang

L : 147 orang

P : 136 orang

Usia 50 - 54 tahun : 232 orang

L : 125 orang

P : 107 orang

Usia 55 - 59 tahun : 182 orang

L : 92 orang

P : 90 orang

Usia $60-64$ tahun : 122 orang

L : 68 orang

$\mathrm{P} \quad$ : 54 orang

Usia 65 tahun ke atas: 203 orang

L : 97 orang

P : 106 orang

(Sumber: Data Desa Gegempalan, 2017)

\section{B. Pelaksanaan Kegiatan Pengabdian}

Sebelum pelaksanaan kegiatan pengabdian, tahap pertama yang harus dilaksanakan adalah persiapan dengan melakukan observasi tentang potensi wisata budaya yang ada di Desa Gegempalan, Kecamatan Cikoneng, Kabupaten Ciamis. Berdasarkan hasil observasi 
potensi wisata sejarah yang ada di Desa Gegempalan adalah Makam Bupati Galuh Kusumadinata I, Kusumadinata II, Batu Panghiasan, Batu Tapak Kidang. Sedangkan, potensi wisata budaya yang ada di Desa Gegempalan adalah Upacara Sedekah Pasarean yang dilaksanakan setahun sekali pada bulan Oktober.

Selanjutnya, setelah tahap persiapan selesai, tim pengabdian langsung melaksanakan kegiatan pengabdian pada tanggal 1 Maret 2019 yang dilaksanakan di Dusun Majaganda Desa Gegempalan dengan tema "Sosialisasi Pentingnya Potensi Wisata Budaya di Desa Gegempalan Kecamatan Cikoneng Kabupaten Ciamis”. Kegiatan tersebut dihadiri oleh perangkat desa Gegempalan serta tokoh masyarakat sebanyak 20 orang dari pukul 13.0015.00. Pada pelaksanaan kegiatan pengabdian ini membahas tentang pentingnya pengelolaan pariwisata budaya yang ada di desa Gegempalan yang bisa dimanfaatkan untuk peningkatan kesejahteraan ekonomi masyarakat, serta UU yang mengatur tentang pariwisata.

\section{Pengertian, Tujuan, Prinsip Pariwisata}

Pariwisata adalah keseluruhan rangkaian kegiatan yang berhubungan dengan pergerakan manusia yang melakukan perjalanan atau persinggahan sementara dari tempat tinggalnya ke suatu atau beberapa tempat tujuan di luar lingkungan tempat tinggalnya yang didorong oleh beberapa keperluan tanpa bermaksud mencari nafkah (Priyanto \&Safitri, 2016). Selain itu, pariwisata dapat didefinisikan sebagai suatu perjalanan dari satu tempat menuju tempat lain yang bersifat sementara, yang biasanya dilakukan orang-orang yang ingin menyegarkan pikiran setelah bekerja terus dan memanfaatkan waktu libur dengan menghabiskan waktu bersama keluarga untuk berekreasi (Sugiyarto \& Amaruli, 2018).

Sedangkan, pengertian pariwisata menurut Undang-undang No. 10 Tahun 2009 Bab 1 Pasal 1 butir 3 menyatakan bahwa pariwisata adalah berbagai macam kegiatan wisata yang didukung berbagai fasilitas serta layanan yang disediakan oleh masyarakat, pengusaha, pemerintah, dan pemerintah daerah. Pariwisata mencakup tiga komponen, yakni wisata, pengusahaan objek, dan daya tarik wisata, serta usaha-usaha lain di luar bidang tersebut, namun masih terkait dengan pariwisata (Astuti et al, 2009). UndangUndang Nomor 10 Tahun 2009 tentang kepariwisataan menyatakan bahwa pembangunan kepariwisataan diperlukan untuk mendorong pemerataan kesempatan berusaha dan memperoleh manfaat serta mampu menghadapi tantangan perubahan kehidupan lokal, nasional, dan global. 
Tujuan penyelenggaraan kepariwisataan diatur dalam Pasal 4 Undang-Undang Nomor 10 Tahun 2009 yang isinya menyatakan bahwa tujuan penyelenggaraan yaitu:

1) Meningkatkan pertumbuhan ekonomi;

2) Meningkatkan kesejahteraan rakyat;

3) Menghapus kemiskinan;

4) Mengatasi Pengangguran;

5) Melestarikan alam, lingkungan dan sumber daya air;

6) Memajukan kebudayaan;

7) Mengangkat citra bangsa;

8) Memupuk rasa cinta tanah air;

9) Memperkukuh jati diri dan kesatuan bangsa;

10) Mempererat persahabatan antar bangsa.

Berdasarkan Undang-Undang No. 10 Tahun 2009 Pasal 5, penyelenggaraan kepariwisataan di Indonesia dilaksanakan dengan prinsip sebagai berikut:

1) Menjunjung tinggi norma agama dan nilai budaya sebagai pengejawantahan dari konsep hidup dalam keseimbangan hubungan antara manusia dan Tuhan YME, hubungan antara manusia dan sesama manusia dan hubungan manusia dengan lingkungan;

2) Menjunjung tinggi hak asasi manusia, keragaman budaya dan kearifan lokal;

3) Memberi manfaat untuk kesejahteraan rakyat, keadilan, kesetaraan dan proporsionalitas;

4) Memelihara kelestarian alam dan lingkungan hidup;

5) Memberdayakan masyarakat setempat;

6) Menjamin keterpaduan antar sektor, antar daerah, antara pusat dan daerah yang merupakan satu kesatuan sistemik dalam kerangka otonomi daerah serta keterpaduan antar pemangku kepentingan;

7) Mematuhi kode etik kepariwisataan dunia dan kesepakatan internasional dalam bidang pariwisata;

8) Memperkukuh keutuhan Negara Kesatuan Republik Indonesia.

Berdasarkan klasifikasi Leiper (1990) dalam Pitana (2009), sistem pariwisata terdiri atas tujuh (7) komponen besar, dimana komponen tersebut merupakan sektor utama dalam kepariwisataan yang memerlukan keterkaitan, ketergantungan, dan keterpaduan, yaitu: 
1) Sektor pemasaran (the marketing sector)

2) Sektor perhubungan (the carrier sector)

3) Sektor akomodasi (the accommodation sector)

4) Sektor daya tarik/atraksi wisata (the attraction sector)

5) Sektor tour operator (the tour operator sector)

6) Sektor pendukung/rupa-rupa (the miscellaneous sector).

7) Sektor pengkoordinasi/ regulator (the coordinating sector)

Pelaku pariwisata adalah setiap pihak yang berperan dan terlibat dalam kegiatan pariwisata. Adapun yang menjadi pelaku pariwisata menurut Damanik dan Weber (2006) adalah:

1) Wisatawan,

2) Industri pariwisata/penyedia jasa,

3) Pendukung jasa wisata,

4) Pemerintah,

5) Masyarakat lokal, dam lembaga swadaya masyarakat.

Menurut Direktoral Jendral Pemerintahan dalam Sunaryo (2013), obyek wisata atau daya tarik wisata dibagi menjadi tiga macam, yaitu:

1) Daya tarik wisata alam adalah daya tarik wisata yang dikembangkan dengan lebih banyak berbasis pada anugrah keindahan dan keunikan yang telah tersedia di alam;

2) Daya tarik wisata budaya adalah daya tarik wisata yang dikembangkan dengan lebih banyak berbasis pada hasil karya dan hasil cipta manusia, baik yang berupa peninggalan budaya (situs/heritage) maupun nilai budaya yang masih hidup (the living culture) dalam kehidupan di suatu masyarakat, yang dapat berupa upacara/ritual, adat istiadat, seni pertunjukan, seni kriya, seni sastra, seni rupa, ataupun keunikan seharihari yang dimiliki oleh suatu masyarakat;

3) Daya tarik wisata minat khusus (special interest) adalah daya tarik wisata yang dikembangkan dengan lebih banyak berbasis pada aktivitas untuk pemenuhan keinginan wisatawan secara spesifik.

Bentuk pariwisata bukan hanya pariwisata alam, tetapi ada pariwisata budaya. Salah satunya, yang terdapat di Desa Gegempalan Kecamatan Cikoneng. Di Desa ini terdapat beberapa wisata budaya, seperti, makam Bupati Galuh yang ke 3, yaitu Kusumadinata I. Bupati Kusumadinata I memerintah Galuh dari tahun 1706-1727. Pada masa pemerintahannya, Galuh dengan kabupaten-kabupaten Priangan lainnya diletakkan di bawah pengawasan pangeran Aria Cirebon hingga tahun 1723. Keturunan Sunan Gunung 
Jati ini diberi wewenang untuk mengawasi tindakan para bupati Priangan dan melakukan berbagai kebijakan sesuai dengan instruksi yang dikeluarkan untuknya pada tanggal 22 Maret 1706. Salah satu perubahan dilakukannya, misalnya, ia mengusulkan kepada VOC agar Bupati Kawasen Sutanangga diganti oleh Patih Ciamis yang dianggap sebagai ningrat tertua dan terpandai. Usul ini dikabulkan VOC. Selain itu, di Desa Gegempalan terdapat pula makam Bupati Galuh ke 4, yaitu Kusumainata II, yang memerintah dari tahun 17271732 M. Kusumadinata II, disebut juga Dalem Kasep, beliau masih bujangan telah meninggal, dimakamkan di Majaganda Kidul satu komplek dengan makam ayahnya berarti beliau tidak mempunyai keturunan, tapi mempunyai dua orang adik berlainan ibu yaitu Danumaya dan Danukriya. Pada saat R. Adipati Kusumadinata II meninggal, kedua adiknya tersebut tidak diangkat menjadi bupati karena menurut kompeni tidak berhak berdasarkan garis keturunan dan dianggap kurang cakap.

Untuk sementara Imbanagara tidak ada bupatinya karena menurut kompeni yang berhak untuk menggantikan bupati adalah R. Ay. Candranagara kakaknya R. Adipati Kusumadinata II. Sementara kakaknya wanita, jadi tidak bisa dijadikan bupati maka menurut kompeni yang berhak menjadi bupati adalah putranya yaitu Mas Garuda tetapi baru berusia 3 tahun. Untuk itu, sambil menunggu Mas Garuda dewasa sementara kedudukannya dipegang oleh ayahnya patih Jagabaya dibantu oleh R. Angganagara Kusumadinata (Dinas Pendidikan dan Kebudayaan Kabupaten Ciamis).

\section{KESIMPULAN DAN SARAN}

\section{Kesimpulan}

Kegiatan sosialisasi pentingnya potensi wisata budaya bagi masyarakat yang ada di Desa Gegempalan berjalan dengan lancar sesuai dengan apa yang direncanakan, meskipun belum semua memahami tentang pentingnya pengelolaan wisata budaya yang ada di desa Gegempalan. Kegiatan sosialisasi ini mendapatkan respon yang sangat baik, hal ini dibuktikan dengan keaktifan peserta sosialisasi yang diikuti tokoh masyarakat sampai tuntas.

\section{Saran}

Berdasarkan evaluasi yang telah dilakukan dapat diajukan beberapa saran sebagai berikut:

1. Waktu pelaksanaan pengabdian perlu ditambah, supaya tujuan kegiatan dapat dicapai sesuai dengan harapan, namun dengan konsekuensi penambahan biaya. 
2. Adanya kegiatan lanjutan yang berupa sosialisasi sejenis dimana hal ini dilakukan secara kontinue, sehingga mampu meningkatkan pemahaman masyarakat tentang pengelolaan potensi wisata budaya.

\section{DAFTAR PUSTAKA}

Astuti, P., Asteriani, F., Sofwan, M., Sardiyanto, E., Studi, P., Wilayah, P., Teknik, F., \& Riau, U. I. (2009). Kajian pengembangan wisata budaya kawasan istana gunung sahilan berdasarkan persepsi masyarakat dan pelaku wisata. 10, 409-419

Damanik, J dan Weber, HF. (2006). Perencanaan Ekowisata Dari Teori ke Aplikasi. Yogyakarta: CV. Andi Offset.

Data Desa Gegempalan. (2017).

Dinas Pendidikan dan Kebudayaan Kabupaten Ciamis. 2014. Kabupaten Ciamis Dalam Sudut Pandang Sejarah dan Nilai Budaya: Pemerintahan Kabupaten Ciamis Dinas Pendidikan dan Kebudayaan.

https://gegempalan.web.id/gambaran-umum

Kemenparekraf. (2009). UU No 10 Tahun 2009 (Hal. 1-44). https://www.kemenparekraf.go.Id/Asset_Admin/Assets/Uploads/Media/Old_File/463 6_1364-Uutentangkepariwisataannet1.Pdf

Munawar, Wawan. (2019). Kepala Desa Gegempalan. 6 Maret 2019.

Priyanto \&Safitri, D. (2016). Pengembangan Potensi Desa Wisata Berbasis Budaya Tinjauan Terhadap Desa Wisata Di Jawa Tengah. Jurnal Vokasi Indonesia, 4(1). https://doi.org/10.7454/jvi.v4i1.53

Sugiyarto, S., \& Amaruli, R. J. (2018). Pengembangan Pariwisata Berbasis Budaya dan Kearifan Lokal. Jurnal Administrasi Bisnis, $7(1), \quad 45$. https://doi.org/10.14710/jab.v7i1.22609

Sunaryo, Bambang. 2013. Kebijakan Pembangunan Destinasi Pariwisata Konsep dan Aplikasinya di Indonesia. Yogyakarta : Gava Media. Pitana, I Gde, and I Ketut Surya Diarta. 2009. Pengantar Ilmu Pariwisata. Yogyakarta: CV. Andi Offset. 